\title{
ANALISIS TERHADAP TINDAK PIDANA PROSTITUSI DIHUBUNGKAN DENGAN ETIKA MORAL SERTA UPAYA PENANGGULANGAN DI KAWASAN CISARUA KAMPUNG ARAB
}

\author{
Mia Amalia \\ Dosen Fakultas Hukum Universitas Suryakancana \\ E-mail: amalia.amalia84@gmail.com
}

\begin{abstract}
ABSTRAK
Fenomena pelacuran merupakan salah satu bentuk kriminalitas yang sangat sulit untuk ditangani dan jenis kriminalitas ini banyak didukung oleh faktor ekonomi dalam kehidupan masyarakat, dimana dalam masyarakat itu sendiri sampai detik ini, prostitusi belum dapat dihentikan, serta sebagai ancaman terhadap sex morality, kehidupan rumah tangga, kesehatan, kesejahteraan kaum wanita. Salah satu permasalahan prostitusi karena banyaknya turis asal negara-negara Timur Tengah (Timteng) datang silih berganti ke Kampung Arab khususnya ke kawasan Puncak Kabupaten Bogor. Terjadinya praktik transaksi seks tidak hanya dengan para PSK dari Bogor dan Cianjur (PSK Domestik) tetapi antara turis Arab dengan PSK asal Maroko yang kerap dijuluki Maghribi. Oleh karena itu, pihak pemerintah harus lebih aktif mencari solusi untuk persoalan seperti ini berani memberantas prostitusi dilokalisasi. Semakin lama budaya Indonesia akan terkikis dari daerah tersebut dan yang paling mengkhawatirkan adalah kasus prostitusi akan beranak pinak sebagai masalah sosial yang berkaitan dengan etika moralitas bangsa.
\end{abstract}

Kata Kunci: Prostitusi, Etika Moral dan Penanggulangan Prostitusi.

\begin{abstract}
Prostitution's phenomenon is one of criminality forms that is very difficult to overcome and this criminality type is widely supported by economic factors in the environment, until now, prostitution cannot be stopped, as well as a treatment to sexual morality, domestic life, health, women's welfare. One of the problems is because the number of tourists from the Middle East came and went to Kampung Arab, the area of Puncak, Bogor regency particularly. The practical sexual transaction not only experiencing by the prostitutes from Bogor and Cianjur (PSK Domestic) but also between Arabic tourists and Moroccos, what we called Maghribi. Therefore, the government should be more active in seeking solutions to this problem, such as eradicating prostitution bravely in brothels. As the time goes by, Indonesian culture will be eroded from that area and the most worrying is the case of prostitution will multiply as social issues related to moral ethics nationally.
\end{abstract}

Keywords: Prostitution, Moral Ethics and Prevention of Prostitution. 


\section{PENDAHULUAN}

Dalam kehidupan bermasyarakat ini memang selalu terjadi masalahmasalah sosial yang terus berkembang sejalan dengan perkembangan zaman, terutama yang berkaitan dengan masalah pelacuran. ${ }^{1}$ Membicarakan pelacuran sama artinya membicarakan persoalan klasik dan kuno tetapi karena kebutuhan untuk menyelesaikannya, maka selalu menjadi relevan dengan setiap perkembangan manusia dimanapun. ${ }^{2}$ Menurut Kartono, pelacuran atau yang sering disebut dengan prostitusi atau pemuas nafsu seks, merupakan jenis pekerjaan yang setua umur manusia itu sendiri. $^{3}$

Prostitusi atau pelacuran sebagai masalah sosial sementara ini dilihat dari hubungan sebab-akibat dan asal mulanya tidak dapat diketahui dengan pasti, namun sampai sekarang pelacuran masih banyak dijumpai dalam kehidupan sehari-hari dan ada di hampir setiap wilayah di Indonesia, baik yang

1 F.X. Rudy Gunawan, Mengebor Kemunafikan: Inul, Sex dan Kekuasaan, Kawan Pustaka, Yogyakarta, 2003, hlm. 21.

2 Anwar Sahid, Polemik Prostitusi Di Indonesia, Surat Kabar Harian Media Indonesia, Nomor XIII, 13 Agustus 2016, hlm. 6 Kolom 3.

3 Suyanto Bagong, Anak Perempuan Yang Dilacurkan, Korban Eksploitasi di Industri Seksual Komersial, Graha Ilmu, Jogjakarta 2012, hlm. 39. dilakukan secara terang-terangan maupun sembunyi-sembunyi. ${ }^{4}$ Masalah prostitusi adalah masalah struktural, permasalahan mendasar yang terjadi dalam masyarakat adalah masih memahami masalah prostitusi sebagai masalah moral. Tidak menyadari persepsi moral ini akan mengakibatkan sikap "menyalahkan korban" yang ujungnya menjadikan korban semakin tertindas. $^{5}$

Pelacuran merupakan salah satu bentuk kriminalitas yang sangat sulit untuk ditangani dan jenis kriminalitas ini banyak didukung oleh faktor ekonomi dalam kehidupan masyarakat, dimana dalam masyarakat itu sendiri mendapat pemenuhan akan kebutuhan secara manusiawi. ${ }^{6}$ Keinginan yang timbul ini merupakan akibat dari nafsu biologis manusia yang sederhana. ${ }^{7}$ Bentuk prostitusi seperti praktik penjualan jasa

4 Hull, T., Sulistyaningsih, E., dan Jones, G.W., Pelacuran di Indonesia: Sejarah dan perkembangannya, Pustaka Sinar Harapan dan Ford Foundation, Jakarta, 1997, hlm. 42.

5 Elizabeth Pisani, Kearifan Pelacur: Kisah Gelap di Balik Bisnis Seks dan Narkoba. Serambi, Jakarta, 2008, hlm. 69.

6 Tjahjo Purnomo, Dol LY (Membedah Dunia Pelacuran Surabaya Kasus Kompleks Pelacuran Dolly), Grafiti Pers, Jakarta, 2010, hlm. 68.

7 Sihombing, G, “Analisis Dan Evaluasi Hukum Tentang Penanggulangan Prostitusi dan Pencegahan Penyebaran HIV/AIDS". Badan Pembinaan Hukum Nasional Departemen Kehakiman RI, Jakarta, 1996, hlm. 27-28. 
seksual atau yang disebut juga pekerja seks komersial selayaknya dianggap sebagai salah satu penyakit masyarakat yang memiliki sejarah panjang, bahkan dianggap sebagai salah satu bentuk penyimpangan terhadap norma perkawinan yang suci. ${ }^{8}$ Sampai detik ini, prostitusi belum dapat dihentikan, pemerintah pun seolah-olah melegalkan praktik yang telah mendarah daging di masyarakat Indonesia ini seperti ancaman terhadap sex morality, kehidupan rumah tangga, kesehatan, kesejahteraan kaum wanita, dan bahkan menjadi problem bagi pemerintah lokal. ${ }^{9}$

Menurut Bonger dalam Mudjijono prostitusi adalah gejala sosial ketika wanita menyediakan dirinya untuk perbuatan seksual sebagai mata pencahariannya. ${ }^{10}$ Commenge dan Soedjono prostitusi adalah suatu perbuatan dimana seorang wanita memperdagangkan atau menjual

8 Simangunsong, et.all., "Analisis Yuridis Mengenai Pertanggungjawaban Pidana Pengguna Jasa Prostitusi Dalam Perspektif KUHP", T.p., t.t, hlm. 39.

9 Amalia, Astry Sandra, "Dampak Lokalisasi Pekerja Seks Komersial (PSK) Terhadap Masyarakat Sekitar (Studi Kasus di Jalan Soekarno-Hatta Km.10 Desa Purwajaya Kabupaten Kutai Kartanegara)", eJournal Administrasi Negara, Volume 1, Nomor 2, 2013: 465-478.

${ }^{10}$ Endang R Setyaningsih Mamahit, PerempuanPerempuan Kramat Tunggak, Kepustakaan Populer Gramedia, Jakarta, 2010, hlm. 44-45. tubuhnya, untuk memperoleh pembayaran dari laki yang datang membayarnya dan wanita tersebut tidak ada mata pencaharian nafkah lain dalam hidupnya kecuali yang diperoleh dengan melakukan hubungan sebentar-sebentar dengan banyak orang. ${ }^{11}$

Prostitusi secara etimologis berasal dari kata prostitutio yang berarti hal menempatkan, dihadapkan, hal menawarkan. $^{12}$ Adapula arti lainnya menjual, menjajakan, namun secara umum diartikan sebagai penyerahan diri kepada banyak macam orang dengan memperoleh balas jasa untuk pemuasan seksual orang itu. Kehidupan para pelaku prostitusi sangatlah primitif. $^{13}$ Dilihat dari segi sosiologinya, dipandang rendah oleh masyarakat sekitar. Seakan akan sebagai makhluk yang tidak bermoral dan meresahkan warga sekitar

11 John Godwin, Pekerjaan Seks dan Hukum di Asia Pasifik: Hukum, HIV, dan Hak Asasi Manusia dalam Konteks Pekerjaan Seks, Oktober, 2012, hlm. 32.

12 Butje Tampi, "Kejahatan Kesusilaan dan Pelecehan Seksual Dalam Hukum Pidana Indonesia", Karya IImiah Universitas Sam Ratulangi Fakultas Hukum Manado, 2010, hlm. 56.

13 Basuki E, Perilaku Beresiko Tinggi terhadap AIDS pada Kelompok Wanita Tuna Susila Kecamatan Pasar Rebo Jakarta Timur, Jakarta, 1991, hlm. 21. 
serta mencemarkan nama baik daerah tempat berasal. ${ }^{14}$

Dilihat dari aspek pendidikan, prostitusi merupakan kegiatan yang demoralisasi. ${ }^{15}$ Dari aspek kewanitaan, prostitusi merupakan kegiatan merendahkan martabat wanita. Dari aspek ekonomi, prostitusi dalam praktiknya sering terjadi pemerasan tenaga kerja. Dari aspek kesehatan, praktik prostitusi merupakan media yang sangat efektif untuk menularnya penyakit kelamin dan kandungan yang sangat berbahaya. Dari aspek kamtibmas praktik prostitusi dapat menimbulkan kegiatan-kegiatan kriminal. Dari aspek penataan kota, prostitusi dapat menurunkan kualitas dan estetika lingkungan perkotaan. ${ }^{16}$

Permasalahan prostitusi di kawasan Cisarua Kampung Arab salah satunya karena banyaknya turis asal negara-negara Timur Tengah (Timteng) datang silih berganti. Di kawasan Warung Kaleng, nyaris setiap bangunan di bibir Jalan Raya Puncak bertuliskan

14 Sumiyanto, "Kecenderungan Wanita Menjadi Korban Tindak Pidana Terhadap Kesusilaan", T.p., t.t, hlm. 33.

15 Adami Chazawi, Kejahatan Terhadap Tubuh dan Nyawa, Raja Grafindo Persada, Jakarta, 2013, hlm. 22

16 Butje Tampi, "Kejahatan Kesusilaan ... OP Cit, hlm. 59. huruf arab. ${ }^{17}$ Terjadinya praktik transaksi seks tidak hanya dengan para PSK dari Bogor dan Cianjur (PSK Domestik) tetapi antara turis Arab dengan PSK asal Maroko yang kerap dijuluki Maghribi. Oleh karena itu, pihak pemerintah harus lebih aktif mencari solusi untuk persoalan seperti ini berani memberantas prostitusi dilokalisasi prostitusi. Kalau tidak, semakin lama budaya Indonesia akan terkikis dari daerah tersebut dan yang paling mengkhawatirkan adalah kasus prostitusi akan beranak pinak disana. ${ }^{18}$

Pelacuran bila dilihat dalam Kitab Undang-Undang Hukum Pidana (KUHP) maka tidak ada satu pasal pun yang mengatur secara khusus terhadap pelaku prostitusi (PSK). ${ }^{19}$ Secara kriminologis sulit untuk mengatakan bahwa pelacuran itu sebagai suatu kejahatan, sebab tidak menimbulkan korban. Di dalam kriminologi pelacuran sering disebut victimless crime (kejahatan tanpa korban), semua pihak yang berperan di dalam pelacuran tidak ada yang

17 Fahira Idris, Di Swedia, "Identitas Pelanggan PSK Dipublikasikan Biar Jera", dalam Selasar.com diakses Jumat, 22 Mei 2015, 06:00 WIB

18 Leden Marpaung, Kejahatan Terhadap Kesusilaan dan Permasalahan Prevensinya, Sinar Grafika, Jakarta, 1996, hlm. 50.

19 E. Fernando M Manullang, Legisme Legalitas dan Kepastian Hukum, Pranadamedia Group, Jakarta, 2016, hlm. 33. 
dirugikan baik WTS, germo, tamu maupun calo pelacuran. ${ }^{20}$

Dilihat delik-delik kesusilaan dalam Kitab Undang-Undang Hukum Pidana (Pasal 281 sampai Pasal 303) khususnya Pasal 296 dan Pasal 506 Kitab Undang-Undang Hukum Pidana (KUHP) tidak ditunjukkan pada Wanita Tuna Susila. Melainkan ditujukan kepada pemilik rumah-rumah bordil yaitu para germo/mucikari dan para calo. melihat detik-detik kesusilaan yang diatur dalam Kitab Undang-Undang Hukum Pidana (KUHP), yakni Pasal 281 sampai Pasal 303, amat sulit diterapkan pada wanita pelacur dan tamu yang datang mengunjunginya. ${ }^{21}$ Kejahatan terhadap kesusilaan yang diatur dalam Kitab Undang-Undang Hukum Pidana (KUHP) buku II bab XIV, dari Pasal 281 sampai dengan $303 .{ }^{22}$ Sehingga setiap razia dan penertiban pelacuran oleh aparatur negara, hampir-hampir tidak pernah ada tamu yang mengunjungi pelacuran tersebut ditangkap, jika berdasarkan pasal-pasal Kitab Undang-

20 A.S Alam, Pelacuran dan Pemerasan Studi Sosiologi tentang Eksploitasi Manusia oleh Manusia, Penerbit Alumni, Bandung, 1984, hlm. 160.

21 Cesare Beccaria, Perihal Kejahatan dan Hukuman, Genta Publishing, Yogyakarta, 2011, hlm. 21.

22 Ahmad Hanafi, Asas-Asas Hukum Pidana Islam, Bulan Bintang, Jakarta, 1990, hlm. 28
Undang Hukum Pidana (KUHP) tersebut di atas, meskipun demikian permasalahan penegakan hukum terhadap prostitusi seharusnya tetap dapat ditertibkan serta ditindak melalui Perda masing-masing setiap daerah khususnya penanganan masalah prostitusi di Kampung Arab Cisarua Bogor. ${ }^{23}$

Dari semua persoalan tersebut jika dilihat pada masa sekarang ini, perlu menyempurnakan atau membuat peraturan perundang-undangan hukum pidana atau KUHP yang baru karena yang berlaku sekarang ini merupakan peninggalan penjajah Belanda yang sudah tidak sesuai lagi dengan perubahan jaman. ${ }^{24}$ Apabila dilihat Pasal 296 dan Pasal 506 Kitab UndangUndang Hukum Pidana (KUHP) tidak ditujukan kepada pelacur akan tetapi ditujukan kepada germo dan calo, sedangkan germo dan calo tersebut tidak

23 Ishaq, "Kontribusi Konsep Jarimah Zina Dalam Pembaharuan Hukum Pidana Indonesia", ljtihad, Jurnal Wacana Hukum Islam dan Kemanusiaan Volume 14, No. 1, Juni 2014: 81-100, hlm. 46.

24 Daniel Andreo, "Analisis Juridis terhadap Pertanggungjawaban Pidana Pelaku Percobaan Tindak Pidana Perdagangan Orang Menurut Undang-Undang Nomor 21 Tahun 2007 (Putusan Pengadilan Negeri Medan Nomor 1.642/Pid.B/2009/PN.Medan)". Jurnal IImiah Fakultas Hukum Universitas Sumatera Utara Medan, 2012, hlm. 23-24. 
diambil tindakan, padahal secara nyata telah melanggar pasal tersebut. ${ }^{25}$

Pangkal hukum pidana Indonesia adalah Kitab Undang-Undang Hukum Pidana (KUHP) yang disebut sebagai hukum pidana umum. ${ }^{26}$ Dari situlah dapat mengetahui bahwa hukum pidana hanya mengategorikan prostitusi sebagai suatu delik terhadap tindak pidana. ${ }^{27}$ Ketentuan lain yang dapat digunakan dalam menjerat praktik prostitusi adalah Undang-Undang Nomor 21 Tahun 2007, tentang Pemberantasan Tindak Pidana Perdagangan Orang. Kemudian UndangUndang Nomor 21 Tahun 2007 tentang Perdagangan Orang, bahwa undangundang ini mengacu pada pemberantasan tindak pidana perdagangan orang, yang di dalamnya termasuk juga dalam hal prostitusi. $^{28}$

Di dalam hukum Islam tidak ditemukan nomenklatur yang secara implisit menyebut prostitusi. Prostitusi adalah penyediaan layanan seksual yang

25 Helmy Boemiya, "Analisis Yuridis Tindak Pidana Perbuatan Zina (Perzinahan) Dalam Perspektif Hukum Islam", T.p.,T.t, hlm. 93.

26 Aziz Syamsuddin, Tindak Pidana Khusus, Sinar Grafika, Jakarta, 2014, hlm. 69.

27 Adami Chazawi, 2007, Tindak Pidana Mengenai Kesopanan, Raja Grafindo Persada, Jakarta, 2005, hlm. 58.

28 Jan Remmelink, Hukum Pidana Komentar Atas Pasal-Pasal Terpenting dari KUHP Belanda dan Padanannya dalam KUHP Indonesia, Gramedia Pustaka Umum, Jakarta, 2003, hlm. 47. dilakukan oleh laki-laki atau perempuan untuk mendapatkan uang atau kepuasan. Inilah yang menjadi permasalahan yang perlu diperjelas status hukumnya, mengingat dalam hukum pidana nasional, istilah zina dengan prostitusi dibedakan deliknya. Hukuman pelaku zina terbagi dua, yaitu muhsan (sudah menikah) dihukum dengan cara dirajam dan ghair muhsan (belum menikah). ${ }^{29}$

Kebijakan yang dilakukan untuk mengatasi prostitusi secara garis besar terdiri dari pertama, legalisasi yakni penutupan praktik prostitusi; kedua, kriminalisasi yakni mengkriminalkan pelaku prostitusi; ketiga, dekriminalisasi yakni upaya untuk mengkriminalkan pelaku prostitusi; dan keempat abolisi, yakni upaya untuk menghapus sampai ke akar-akarnya praktik prostitusi, karena prostitusi dianggap sebagai perbudakan. Indonesia termasuk negara yang menerapkan kebijakan kriminalisasi. Namun pada praktiknya prostitusi tidak pernah habis dan malah tumbuh subur. Perlukan merubah kebijakan dari kriminalisasi menuju abolisi. ${ }^{30}$

29 Dian Andriasari, "Studi Komparatif Tentang Zina dalam Hukum Indonesia dan Hukum Turki", Jurnal Syiar Hukum FH Unisba. Vol. XIII. No. 3 November 2011, hlm. 39-40

30 Anwar Yesmil, Saat Menuai Kejahatan, Sebuah Pendekatan Sosiokultural Kriminologi, Hukum dan HAM, PT Refika Aditama, Bandung, 2009, hlm. 29. 
Berdasarkan latar belakang di atas ada beberapa hal yang dijadikan permasalahan yaitu sebagai berikut: 1) Bagaimana pertanggungjawaban para pihak yang terlibat dalam prostitusi? 2) Bagaimana analisis etika dan moral terhadap tindak pidana prostitusi? 3) Upaya-upaya hukum apa yang dapat dilakukan untuk mencegah dan menanggulangi terjadinya tindak pidana prostitusi?

\section{II.PEMBAHASAN}

Hukum yang baik menurut Lawrence Friedman harus selalu memuat unsur-unsur sistem hukum yang terdiri dari 3 (tiga) bagian yaitu struktur hukum (legal structure), substansi hukum (legal substance) dan budaya hukum (legal culture). ${ }^{31}$ Oleh karena itu, segala sesuatu yang akan dilaksanakan dalam sebuah sistem hukum nasional atau negara harus disesuaikan dengan kondisi dan kepentingan atau tujuan negara yang bersangkutan.

Setiap masyarakat atau bangsa tentu memiliki pandangan hidup yang berisi nilai-nilai moral atau etika yang

31 Lawrence Friedman, American Law, London: W.W. Norton \& Company, dalam bukunya Yopi Gunawan dan Kristian, Perkembangan Konsep Negara Hukum \& Negara Hukum Pancasila, Refika Aditama, Bandung, 2015, hlm. 1. dianggap sebagai "suatu kebenaran". Moral dan etika atau "suatu kebenaran" itu pada dasarnya memuat suatu nilainilai yang dianggap baik atau tidak baik, sesuatu yang dianggap benar atau tidak benar, sesuatu yang dianggap patut atau tidak patut, sesuatu yang dianggap layak atau tidak layak dan sesuatu yang dianggap adil atau tidak adil. Nilai yang dianggap sebagai "suatu kebenaran" oleh suatu masyarakat atau bangsa sudah tentu harus dijadikan jiwa, pandangan hidup dan cita-cita yang akan dijadikan dasar dalam menjalankan kehidupan bermasyarakat, berbangsa dan bernegara dan "suatu kebenaran" tersebut tentunya akan dijunjung tinggi serta akan dilaksanakan dengan kesadaran dan tanpa paksaan. ${ }^{32}$

Disahkannya Undang-Undang Dasar (UUD) 1945 sebagai konstitusi negara Indonesia, membawa dampak terhadap segala aturan hukum yang berlaku di Indonesia senantiasa harus bersumber dari UUD tersebut terutama dalam pembukaan UUD 1945 yang merupakan asas kerohanian yang di dalamnya terdapat dasar filsafat negara Pancasila (Philosofische Groundslag).

32 Yopi Gunawan dan Kristian, Perkembangan Konsep Negara Hukum \& Negara Hukum Pancasila, Refika Aditama, Bandung, 2015, hlm. 4. 
Indonesia yang memutuskan Pancasila sebagai dasar negaranya menjadikan Pancasila sebagai sumber hukum materiil, karena setiap isi peraturan perundang-undangan baik yang dikeluarkan oleh pemerintah pusat maupun pemerintah daerah tidak boleh bertentangan dengannya. Ideologi Pancasila khususnya yang termanifestasi dalam sila ketiga 'Persatuan Indonesia' kemudian diterjemahkan melalui Konstitusi UUD Tahun 1945, Pasal 1 Ayat (1) 'Negara Indonesia ialah Negara Kesatuan, yang berbentuk Republik', selanjutnya Pasal 18 Ayat (1) 'Negara Kesatuan Republik Indonesia dibagi atas daerah-daerah provinsi dan daerah provinsi itu dibagi atas kabupaten dan kota, yang tiap-tiap provinsi, kabupaten, dan kota itu mempunyai pemerintahan daerah, yang diatur dengan undangundang'.

Konsep negara hukum Indonesia yang berdasarkan Pancasila dan UndangUndang Dasar 1945 dapat dilihat secara material dan yuridis formal. Secara material negara hukum Pancasila didasarkan pada paradigma bangsa Indonesia dalam bernegara yang bersifat integralistik khas Indonesia, yaitu berasas kekeluargaan yang bermakna keutamaan bagi rakyat, penghargaan terhadap harkat dan martabat manusia dan keberlakuan hukum yang berfungsi memberikan pengayoman untuk tegaknya demokrasi, keadilan sosial dan peri kemanusiaan. ${ }^{33}$

Menurut Jimly Asshiddiqie, ide negara hukum, selain terkait dengan konsep rechtstaat dan the rule of law, juga berkaitan dengan konsep nomocracy yang berasal dari perkataan nomos dan cratos. Faktor penentu dalam penyelenggaraan kekuasaan adalah norma atau hukum, sehingga istilah nomocracy tersebut berkaitan erat dengan pemikiran mengenai kedaulatan hukum atau prinsip hukum sebagai kekuasaan tertinggi. ${ }^{34}$

Dengan demikian, sejak kelahirannya, konsep negara hukum atau rule of law ini memang dimaksudkan sebagai usaha untuk membatasi kekuasaan penguasa negara agar tidak menyalahgunakan kekuasaan untuk menindas rakyatnya (abuse of power, abuse de droit). Atas dasar itu, dapat dikatakan bahwa dalam suatu negara

33 Padmo Wahyono, Pembangunan Hukum di Indonesia, Ind-Hill Co, Jakarta, 1989, hlm. 153-155.

34 Jimly Asshiddiqie, Cita Negara Hukum Indonesia, Pidato Orasi IImiah Pada Wisuda Sarjana Hukum Fakultas Hukum Sriwijaya Palembang Tanggal 23 Maret 2004, dimuat dalam Jurnal Hukum Simbur Cahaya No. 25 Tahun IX Mei 2005, hlm. 166. 
hukum, semua orang harus tunduk kepada hukum secara sama, yakni tunduk kepada hukum yang adil. ${ }^{35}$

Dalam negara hukum, hukum ditempatkan sebagai aturan main dalam penyelenggaraan kenegaraan, pemerintahan, dan kemasyarakatan, sementara tujuan hukum itu sendiri antara lain “...opgelegd om de samenleving vreedzaam, rechtvaardig, en doelmatig te ordenen" ${ }^{36}$. Artinya sasaran dari negara hukum adalah terciptanya kegiatan kenegaraan, pemerintahan, dan kemasyarakatan yang bertumpu pada keadilan, kedamaian, dan kemanfaatan atau kebermaknaan.

Suatu negara dapat dikatakan sebagai negara hukum apabila dalam kehidupan bernegara tercakup 4 (empat) tuntutan dasar yaitu sebagai berikut: 1) Tuntutan kepastian hukum yang merupakan kebutuhan langsung masyarakat; 2) Tuntutan bahwa hukum berlaku sama bagi segenap penduduk dan warga negara; 3) Legitimasi demokratis dimana proses pembentukan hukum harus mengikutsertakan dan mendapat persetujuan rakyat; dan 4)

35 Munir Fuady, Teori Negara Hukum Modern (Rechtstaat) Cet Ke-2, Refika Aditama, Bandung, 2009, hlm. 2.

36 N.E. Algra dan H.C.J.G. Jansen, Rechtsingang Een Orientasi in Het Recht, H.D. Tjeenk Willink bv, Groningen, 1974, hlm. 10 .
Tuntutan akal budi yaitu menjunjung tinggi harkat dan martabat manusia dan masyarakat. $^{37}$

Prostitusi di Indonesia dianggap sebagai kejahatan terhadap moral atau kesusilaan dan kegiatan prostitusi adalah sebuah kegiatan yang ilegal dan bersifat melawan hukum, maka berdasarkan hal di atas bahwa bangsa Indonesia merupakan negara hukum salah satunya adalah tuntutan akal budi menjunjung tinggi harkat dan martabat manusia dan masyarakat terhindar dari permasalahan prostitusi.

Dalam Kamus Inggris-Indonesia, Indonesia-Inggris, oleh John M. Echols dan Hassan Shadili prostitusi diartikan pelacuran, persundalan, ketunasusilaan. ${ }^{38}$ Kemudian Syamsudin, mengatakan bahwa menurut istilah prostitusi diartikan sebagai pekerja yang bersifat menyerahkan diri atau menjual jasa kepada umum untuk melakukan perbuatan-perbuatan seksual dengan mendapatkan upah sesuai apa yang diperjanjikan sebelumnya. ${ }^{39}$ Prostitusi atau Pelacuran adalah penjualan jasa

\footnotetext{
37 Franz Magnis Suseno, Etika Politik: Prinsipprinsip Moral Dasar Kenegaraan Modern, Gramedia, Jakarta, 1991, hlm. 292-297.

38 Siska Lis Sulistiani, Kejahatan dan Penyimpangan Seksual Dalam Perspektif Hukum Islam dan Hukum Positif Indonesia, Nuansa Aula, Bandung, 2016, hlm. 124.

39 Ibid, hlm. 126.
} 
seksual, seperti seks oral atau berhubungan seks. Seseorang yang menjual jasa seksual disebut pelacur atau biasa disebut pekerja seks komersial (PSK). Kegiatan prostitusi adalah sebuah kegiatan yang patut ditabukan karena secara moral dianggap bertentangan dengan nilai agama dan kesusilaan.

\section{A. Pertanggungjawaban Para Pihak} yang Terlibat dalam Prostitusi

Dalam menanggapi prostitusi hukum di berbagai negara berbeda-beda, ada yang mengategorikan sebagai tindak pidana, namun ada pula yang bersikap diam dengan beberapa pengecualian, Indonesia termasuk yang bersikap diam dengan pengecualian. Pangkal hukum pidana Indonesia adalah Kitab UndangUndang Hukum Pidana (KUHP) sebagai apa yang disebut hukum pidana umum. Disamping itu terdapat pula hukum pidana khusus sebagaimana yang tersebar di berbagai perundangundangan lainnya. Berkaitan dengan prostitusi KUHP mengaturnya dalam dua pasal, yaitu Pasal 296 dan Pasal 506. Pasal 296 menyatakan "barang siapa dengan sengaja menyebabkan atau memudahkan perbuatan cabul oleh orang lain, dan menjadikannya sebagai pencaharian atau kebiasaan, diancam

dengan pidana penjara paling lama satu tahun empat bulan atau denda paling banyak lima belas ribu rupiah". Sedangkan Pasal 506 menyatakan "barang siapa menarik keuntungan dari perbuatan cabul seseorang wanita dan menjadikannya sebagai pelacur, diancam dengan pidana kurungan paling lama satu tahun".

Dari situlah dapat mengetahui bahwa hukum pidana hanya mengategorikan prostitusi sebagai suatu tindak pidana terhadap pihak perantaranya. Dalam hal ini kepolisian hanya mempunyai ruang gerak untuk melakukan tindakan hukum terhadap perantara, bilamana terdapat perantara (germo atau mucikari). Kegiatan prostitusi akan tetap berjalan selama masih banyak pelanggan. Ketentuan lain yang mungkin dapat digunakan dalam menjerat praktik prostitusi adalah Undang-Undang Nomor 21 Tahun 2007 tentang Pemberantasan Tindak Pidana Perdagangan Orang dan/atau UndangUndang Nomor 23 Tahun 2002 jo Undang-Undang Nomor 35 Tahun 2014 tentang Perlindungan Anak. Manakala menilik Undang-Undang Nomor 21 Tahun 2007, yang di dalamnya termasuk juga dalam hal prostitusi. Pelacur adalah profesi yang menjual jasa untuk 
memuaskan kebutuhan seksual adalah cabang utama filsafat yang pelanggan. Biasanya pelayanan ini dalam bentuk menyewakan tubuhnya. Undang-Undang No 11 Tahun 2008 Tentang Informasi dan Transaksi Elektronik dan Undang-Undang Nomor 44 Tahun 2008 Tentang Pornografi dapat menjerat permasalahan tindak pidana prostitusi di Indonesia.

Pelacuran atau prostitusi adalah penjualan jasa seksual dengan uang sebagai imbalan atau upah. Seseorang yang menjual jasa seksual disebut pelacur, yang kini sering disebut dengan istilah pekerja seks komersial (PSK). Dalam pengertian yang lebih luas, seseorang yang menjual jasanya untuk hal yang dianggap tak berharga juga disebut melacurkan dirinya. Di Indonesia pelacur sebagai pelaku prostitusi atau pelacuran sering disebut sebagai sundal. Ini menunjukkan bahwa prilaku perempuan sundal itu sangat buruk, hina dan menjadi musuh masyarakat. Pelacur dianggap melecehkan kesucian agama dan juga sering diseret ke pengadilan karena melanggar hukum.

\section{B. Analisis Etika terhadap Prostitusi}

Menurut bahasa Yunani Kuno, etika berasal dari kata ethikos yang berarti "timbul dari kebiasaan". Etika

mempelajari nilai atau kualitas yang menjadi studi mengenai standar dan penilaian moral. Etika mencakup analisis dan penerapan konsep seperti benar, salah, baik, buruk, dan tanggung jawab. Etika terbagi menjadi tiga bagian utama: meta-etika (studi konsep etika), etika normatif (studi penentuan nilai etika), dan etika terapan (studi penggunaan nilai-nilai etika). Kata etika, seringkali disebut pula dengan kata etik, atau ethics (bahasa Inggris), mengandung banyak pengertian. Dari segi etimologi (asal kata), istilah etika berasal dari kata Latin "Ethicos" yang berarti kebiasaan. Dengan demikian menurut pengertian yang asli, yang dikatakan baik itu apabila sesuai dengan kebiasaan masyarakat. Kemudian lambat laun pengertian ini berubah, bahwa etika adalah suatu ilmu yang membicarakan masalah perbuatan atau tingkah laku manusia, mana yang dapat dinilai baik dan mana yang dapat dinilai tidak baik. Etika juga disebut ilmu normatif, maka dengan sendirinya berisi ketentuanketentuan (norma-norma) dan nilai-nilai yang dapat digunakan dalam kehidupan sehari-hari. ${ }^{40}$

40 Aripin Banusuru, Filsafat dan Filsafat IImu dari Hakikat ke Tanggung Jawab, Penerbit Alfabeta, Bandung, 2014, hlm. 120-121. 
Pengertian Etika Menurut para Ahli Etika adalah ilmu tentang apa yang baik, apa yang buruk dan tentang hak dan kewajiban moral. Pengertian ini muncul mengingat etika berasal dari bahasa Yunani kuno "ethos" (jamak: ta etha), yang berarti adat kebiasaan, cara berkikir, akhlak, sikap, watak, cara bertindak. Kemudian diturunkan kata ethics (Inggris), etika (Indonesia). ${ }^{41}$

Sekaligus lebih mampu memahami pengertian etika yang sering sekali muncul dalam pembicaraan sehari-hari, baik secara lisan maupun tertulis. Objek etika adalah alam yang berubah, terutama alam manusia. ${ }^{42}$

Pengertian etika menurut para ahli ada beberapa para ahli yang mengungkapkan pengertian-pengertian etika. Diantaranya:

1. James J. Spillane SJ: Etika ialah mempertimbangkan atau memperhatikan tingkah laku manusia dalam mengambil suatu keputusan yang berkaitan dengan moral. Etika lebih mengarah pada penggunaan akal budi manusia dengan objektivitas untuk menentukan benar atau salahnya serta

41 Juhaya S Praja, Aliran-Aliran Filsafat dan Etika, Kencana, Jakarta, 2008, hlm. 162.

42 Darsono Prawironegoro, Filsafat IImu, Nusantara Consulting, Jakarta, 2010, hlm. 122. tingkah laku seseorang kepada orang lain;

2. Franz Magnis Suseno: Etika merupakan suatu ilmu yang memberikan arahan, acuan dan pijakan kepada tindakan manusia;

3. Soergarda Poerbakawatja: Etika merupakan sebuah filsafat berkaitan dengan nilai-nilai, tentang baik dan buruknya tindakan dan kesusilaan;

4. Burhanudin Salam: Mengungkapkan bahwa etika ialah suatu cabang ilmu filsafat yang berbicara tentang nilai-nilai dan norma yang dapat menentukan perilaku manusia dalam kehidupannya;

5. O.P. Simorangkir: Menjelaskan bahwa etika ialah pandangan manusia terhadap baik dan buruknya perilaku manusia;

6. A. Mustafa: Mengungkapkan etika sebagai ilmu yang menyelidiki terhadap perilaku mana yang baik dan yang buruk dan juga dengan memperhatikan perbuatan manusia sejauh apa yang telah diketahui oleh akal pikiran;

7. W.J.S. Poerwadarminto: Menjelaskan etika sebagai ilmu pengetahuan mengenai asas-asas atau dasar-dasar moral dan akhlak. ${ }^{43}$

43 Burhanuddin Salam, Etika Individual Pola Dasar Filsafat Moral, Rineka Cipta, Jakarta, 2000, hlm. 201. 
Etika dan hukum memiliki landasan yang sama, yaitu moral. Moral yang menjadi dasar dari etika dan hukum itu bisa berbeda-beda di masyarakat, apalagi kalau sudah meliputi masyarakat dunia. Setiap Negara memiliki nilai-nilai moral yang berbeda. Sebagai bukti dan contoh, di Indonesia prostitusi walaupun saling suka merupakan prilaku yang dianggap tidak bermoral, akan tetapi jika melihat di Amerika prostitusi dinilai sebagai hal-hal yang wajar saja walau dilakukan atas dasar saling menyukai. Maka hukum yang menaungi kedua Negara itu pun berbeda, Indonesia menghukum setiap aktivitas prostitusi walaupun suka sama suka, sedangkan di Amerika walaupun dilakukan suka sama suka, tidak mendapat hukuman. Jika dicermati lagi, terlihat bahwa setiap negara memiliki nilai-nilai moral yang berbeda, sehingga begitu juga dengan hukum yang menaungi negara tersebut pun turut berbeda. ${ }^{44}$

Dengan pemahaman awal itu, maka dimanakah sebenarnya letak etika. Etika juga memiliki landasan yang sama dengan hukum, yaitu moral. Tapi etika merupakan sandaran dari nilai-nilai hukum. Setiap nilai-nilai hukum itu pasti

44 Jujun S Suriasumantri, Filsafat IImu Sebuah Pengantar Populer, Pustaka Sinar Harapan, Jakarta, 2003, hlm. 391. termuat dalam etika, mungkin dalam penjelasan ini masih agak sedikit dipahami. Jadi seperti ini, nilai-nilai etika itu hampir seluruhnya dicakup oleh hukum, yang perlu digarisbawahi di sini adalah hampir seluruhnya ${ }^{45}$ Etika dalam berhubungan sosial adalah harus saling menyayangi dan saling menghormati sesama manusia, dan jika suatu ketika terjadi pembunuhan maka hukum bertindak sebab telah diusik keberadaannya. Itulah bukti keterkaitan antara etika dan hukum yang mendukung pernyataan bahwa kebanyakan nilai-nilai etika itu juga dicakup oleh hukum.

Etika profesi menurut Keiser adalah sikap hidup berupa keadilan untuk memberikan pelayanan profesional terhadap masyarakat dengan penuh ketertiban dan keahlian sebagai pelayanan dalam rangka melaksanakan tugas berupa kewajiban terhadap masyarakat. Kode etik profesi adalah sistem norma, nilai dan aturan professional tertulis yang secara tegas menyatakan apa yang benar dan baik, dan apa yang tidak benar dan tidak baik bagi professional dengan adanya kode

45 Surajiyo, Filsafat Ilmu dan Perkembangannya di Indonesia, Kanisius, Yogyakarta, 2009, hlm. 312. 
etik akan melindungi perbuatan yang tidak profesional. ${ }^{46}$

Ada beberapa macam etika yang harus dipahami bersama dalam menentukan baik dan buruknya prilaku manusia:

1. Etika Deskriptif, yaitu etika yang berusaha meneropong secara kritis dan rasional sikap dan prilaku manusia dan apa yang dikejar oleh manusia dalam hidup ini sebagai sesuatu yang bernilai. Etika deskriptif memberikan fakta sebagai dasar untuk mengambil keputusan tentang prilaku atau sikap yang mau diambil. Etika deskriptif dapat disimpulkan sebagai bentuk implementasi perbuatan serta perilaku yang diterapkan setiap manusia merupakan landasan pergaulan kehidupan antar manusia dalam ruang lingkup lingkungan masyarakat;

2. Etika Normatif, yaitu etika yang berusaha menetapkan berbagai sikap dan pola prilaku ideal yang seharusnya dimiliki oleh manusia dalam hidup ini sebagai sesuatu yang bernilai. Etika normatif memberi penilaian sekaligus memberi norma sebagai dasar dan kerangka tindakan

46 Arief Sidharta, Apakah Filsafat dan Filsafat Ilmu, Pustaka Sutra, Bandung, 2008, hlm. 129. yang akan diputuskan. Etika normatif ini berusaha mencari ukuran umum bagi baik buruknya tingkah laku;

3. Meta-etika. Mengkaji ungkapanungkapan etis, istilah-istilah teknik etika dan bahasa-bahasa etis yang kajiannya didasarkan pada kelogisannya; ${ }^{44}$

Etika secara umum dapat dibagi menjadi: ${ }^{48}$

1. Etika Umum, berbicara mengenai kondisi-kondisi dasar bagaimana manusia bertindak secara etis, bagaimana manusia mengambil keputusan etis, teori-teori etika dan prinsipprinsip moral dasar yang menjadi pegangan bagi manusia dalam bertindak serta tolak ukur dalam menilai baik atau buruknya suatu tindakan. Etika umum dapat dianalogkan dengan ilmu pengetahuan, yang membahas mengenai pengertian umum dan teori-teori;

2. Etika Khusus, merupakan penerapan prinsip-prinsip moral dasar dalam bidang kehidupan yang khusus. Penerapan ini bisa berwujud: Bagaimana saya mengambil kepu-

44 Aripin Banasuru, Filsafat dan Filsafat IImu ....Op Cit, hlm. 133.

48 Rizal Mustansyir dan Misnal Munir, Filsafat Ilmu, Pustaka Pelajar, Yogyakarta, 2001, hlm. 121. 
tusan dan bertindak dalam bidang kehidupan dan kegiatan khusus yang saya lakukan, yang didasari oleh cara, teori dan prinsip-prinsip moral dasar. Namun, penerapan itu dapat juga berwujud: Bagaimana saya menilai perilaku saya dan orang lain dalam bidang kegiatan dan kehidupan khusus yang dilatarbelakangi oleh kondisi yang memungkinkan manusia bertindak etis: cara bagaimana manusia mengambil suatu keputusan atau tindakan, dan teori serta prinsip moral dasar yang ada dibaliknya. Etika Khusus dibagi lagi menjadi dua bagian:

a. Etika individual, yaitu menyangkut kewajiban dan sikap manusia terhadap dirinya sendiri;

b. Etika sosial, yaitu berbicara mengenai kewajiban, sikap dan pola perilaku manusia sebagai anggota umat manusia.

Perlu diperhatikan bahwa etika individual dan etika sosial tidak dapat dipisahkan satu sama lain dengan tajam, karena kewajiban manusia terhadap diri sendiri dan sebagai anggota umat manusia saling berkaitan. Etika sosial menyangkut hubungan manusia dengan manusia baik secara langsung maupun secara kelembagaan (keluarga, masyarakat, negara), sikap kritis terhadap pandangan-pandangan dunia dan ideologi-ideologi maupun tanggung jawab umat manusia terhadap lingkungan hidup.

Menurut

Prawironegoro menunjukkan teori etika atas lima jenis yaitu: ${ }^{50}$

a. Utilitarianisme yaitu suatu tindakan dianggap benar dan baik jika tindakan itu bermanfaat bagi dirinya dan orang lain;

b. Deontologi yaitu suatu tindakan dianggap benar dan baik jika tindakan itu didasarkan pada suatu kewajiban;

c. Teori hak yaitu suatu tindakan dianggap benar dan baik jika didasarkan martabat manusia, dimana setiap kewajiban terdapat hak;

d. Teori keutamaan yaitu suatu tindakan dianggap benar dan jika didasarkan pada kejujuran, kewajaran, kepercayaan dan keuletan;

Dari berbagai teori diatas, hakikatnya menjelaskan tindakantindakan dapat dipandang dari dua sudut yaitu benar salah atau adil tidak adil.

50 Aripin Banasuru, Filsafat dan Filsafat IImu,... Op Cit, hlm. 132. 
C. Upaya-upaya yang Dapat kebijakan penghapusan prostitusi di

Dilakukan untuk Mencegah dan muka bumi dengan cara menerapkan Menanggulangi Tindak Pidana peraturan perundang-undangan secara

Prostitusi

Berbagai upaya telah dilakukan untuk menghapuskan prostitusi, tetapi tetap saja ada dan tidak dapat dihilangkan, mengingat praktik prostitusi itu telah sama tuanya dengan kehidupan manusia sendiri. Pandangan bahwa prostitusi merupakan perilaku kotor dan tidak bermoral serta salah satu penyakit sosial adalah fakta yang tidak dapat terbantahkan pula. "Tapi tidak mungkin pula untuk menghapuskan prostitusi adalah juga fakta tidak terbantahkan. Karena itu, penanganan prostitusi tidak dapat dilakukan secara sembarangan dan tidak hanya melihat berdasarkan aspek moral semata. Prostitusi adalah persoalan yang rumit dan terkait aspek sosial, budaya, ekonomi, politik serta moral dan agama. Dalam hal ini Pemerintah bersama seluruh masyarakat disarankan untuk menggunakan pendekatan sosial, budaya, ekonomi, politik selain moral dan agama untuk mencari penyelesaian.

Kebijakan yang dapat diterapkan di Indonesia untuk mencegah dan menanggulangi prostitusi adalah kebijakan abolisi. Abolisi adalah konsisten. Upaya ini dilakukan dengan langkah komprehensif dengan penegakan hukum dan pemberitaan di media massa atau online bagi pelaku prostitusi. Dengan pemberitaan ini, maka dipastikan pelaku prostitusi akan jera. Kebijakan ini dilakukan di negara Swedia dengan memberlakukan undangundang (Sex Purchase Law) pada 1 Januari 1999. Persentase prostitusi menurun tajam melebihi 50 persen dibandingkan sebelum tahun 1999. Persentase ini meliputi praktik prostitusi di jalanan, rumah-rumah bordil, hotel, maupun apartemen yang transaksinya dilakukan secara langsung atau tidak langsung. Pengadilan akan menjatuhkan hukuman bagi pelaku dengan bentuk hukuman berupa kerja sosial, denda, hingga dijebloskan penjara paling lama satu tahun. Terhadap korban (pelaku prostitusi, Swedia memberikan pendidikan, pelatihan, pemberdayaan untuk dapat kembali ke masyarakat, dan rehabilitasi).

Kebijakan penanganan prostitusi di Swedia nampaknya patut dicoba di Indonesia terutama penanganan prostitusi di kawasan Cisarua Kampung 
Arab. Upaya dilakukan dengan membuat undang-undang tentang larangan praktik prostitusi secara nasional sebagai peraturan induk yang dapat diikuti oleh aturan vertikal maupun horisontal yang bersifat teknis. Perlu adanya keseriusan politik (political will) untuk melaksanakan kebijakan ini. Nilai-nilai yang terkandung dalam undang-undang terkait prostitusi di Swedia mengandung aspek penjera sebagai tujuan pidana untuk mencegah dan memberantas prostitusi.

\section{PENUTUP}

Pihak-pihak yang terlibat dalam prostitusi, yang dapat dipertanggungjawabkan secara pidana, yaitu: Calo, yaitu calo lokasi dan calo yang perannya. PSK dan pelanggan, yaitu PSK dan pelanggan di lokasi serta Pedagang atau penjual wanita yang dalam kasus perannya dijalankan. Mucikari, yaitu mucikari yang ada di lokasi. Pihak keamanan di lokasi dan Pemilik lokasi, yaitu pemilik lokasi.

Prostitusi di Indonesia dianggap sebagai kejahatan terhadap moral atau etika kesusilaan dan kegiatan prostitusi adalah sebuah kegiatan yang ilegal dan bersifat melawan hukum, maka berdasarkan hal di atas menyatakan bangsa Indonesia merupakan negara hukum salah satunya adalah tuntutan akal budi menjunjung tinggi harkat dan martabat manusia dan masyarakat terhindar dari permasalahan prostitusi. Etika dan hukum memiliki landasan yang sama, yaitu moral. Moral yang menjadi dasar dari etika dan hukum itu bisa berbeda-beda di masyarakat, apalagi kalau sudah meliputi masyarakat dunia. Setiap Negara memiliki nilai-nilai moral yang berbeda.

Kebijakan yang dapat diterapkan di Indonesia untuk mencegah dan menanggulangi prostitusi adalah kebijakan abolisi. Abolisi adalah kebijakan penghapusan prostitusi di muka bumi dengan cara menerapkan peraturan perundang-undangan secara konsisten. Upaya ini dilakukan dengan langkah komprehensif dengan penegakan hukum dan pemberitaan di media massa atau online bagi pelaku prostitusi. 


\section{DAFTAR PUSTAKA}

\section{A. Buku}

Ahmad, Hanafi, Asas-Asas Hukum Pidana Islam, Jakarta: Bulan Bintang, 1990.

Adami Chazawi, Tindak Pidana Mengenai Kesopanan, Raja Grafindo Persada, Jakarta, 2005.

Arief Sidharta, Apakah Filsafat dan Filsafat Ilmu, Pustaka Sutra, Bandung, 2008.

Kejahatan terhadap Tubuh dan Nyawa, Raja Grafindo Persada, Jakarta, 2013.

\section{Tindak Pidana}

Pornografi, Sinar Grafika, Jakarta, 2016.

Anwar Yesmil, Saat Menuai Kejahatan, Sebuah Pendekatan Sosiokultural Kriminologi, Hukum dan HAM, PT Refika Aditama, Bandung, 2009.

Aziz Syamsuddin, Tindak Pidana Khusus, Sinar Grafika, Jakarta, 2014

Aripin Banusuru, Filsafat dan Filsafat Ilmu Dari Hakikat ke Tanggung Jawab, Penerbit Alfabeta, Bandung, 2014.

Basuki E, Perilaku Beresiko Tinggi Terhadap AIDS pada Kelompok Wanita Tuna Susila Kecamatan Pasar Rebo Jakarta Timur, Jakarta, 1991.

Burhanuddin Salam, Etika Individual Pola Dasar Filsafat Moral, Rineka Cipta, Jakarta, 2000.
Cesare Beccaria, Perihal Kejahatan dan Hukuman, Genta Publishing, Yogyakarta, 2011.

Darsono Prawironegoro, Filsafat Ilmu, Nusantara Consulting, Jakarta, 2010.

Endang R Setyaningsih Mamahit, Perempuan-perempuan Kramat Tunggak, Kepustakaan Populer Gramedia, Jakarta, 2010.

E. Fernando M Manullang, Legisme Legalitas dan Kepastian Hukum, Pranadamedia Group, Jakarta, 2016.

Franz Magnis Suseno, Etika Politik: Prinsip-prinsip Moral Dasar Kenegaraan Modern, Gramedia, Jakarta, 1991.

F.X. Rudy Gunawan. Mengebor Kemunafikan: Inul, Sex, dan Kekuasaan. Yogyakarta: Kawan Pustaka. 2003

Hull, T., Sulistyaningsih, E., dan Jones, G.W., Pelacuran di Indonesia: Sejarah dan Perkembangannya, Pustaka Sinar Harapan dan Ford Foundation, Jakarta, 1997.

Jan Remmelink, Hukum Pidana Komentar Atas Pasal-pasal Terpenting dari KUHP Belanda dan Padanannya Dalam KUHP Indonesia, Gramedia Pustaka Umum, Jakarta, 2003

Jujun S Suriasumantri, Filsafat Ilmu Sebuah Pengantar Populer, 
Pustaka Sinar Harapan, Jakarta, 2003

Juhaya S Praja, Aliran-aliran Filsafat dan Etika, Kencana, Jakarta, 2008

Lawrence Friedman, American Law, London: W.W. Norton \& Company, dalam bukunya Yopi Gunawan dan Kristian, Perkembangan Konsep Negara Hukum \& Negara Hukum Pancasila, Refika Aditama, Bandung, 2015.

Munir Fuady, Teori Negara Hukum Modern (Rechtstaat), Refika Aditama, Bandung, Cetakan Kedua, 2009

Leden Marpaung. Kejahatan Terhadap Kesusilaan dan Permasalahan Prevensinya, Jakarta: Sinar Grafika, 1996.

N.E. Algra dan H.C.J.G. Jansen, Rechtsingang Een Orientasi in Het Recht, H.D. Tjeenk Willink bv, Groningen, 1974

Padmo Wahyono, Pembangunan Hukum di Indonesia, Ind-Hill Co, Jakarta, 1989

Elizabeth Pisani. Kearifan Pelacur: Kisah Gelap di Balik Bisnis Seks dan Narkoba. Jakarta: Serambi, 2008.

Prasetyo Teguh, Kriminalisasi dalam Hukum Pidana, Cet I, Nusa Media, Bandung, 2010.

Rizal Mustansyir dan Misnal Munir, Filsafat Ilmu, Pustaka Pelajar, Yogyakarta, 2001.
Surajiyo, Filsafat Ilmu dan Perkembangannya di Indonesia, Kanisius, Yogyakarta, 2009.

Suyanto Bagong, Anak Perempuan yang Dilacurkan, Korban Eksploitasi di Industri Seksual Komersial, Graha Ilmu, Jogjakarta 2012

Siska Lis Sulistiani, Kejahatan dan Penyimpangan Seksual Dalam Perspektif Hukum Islam dan Hukum Positif Indonesia, Nuansa Aula, Bandung, 2016

Tjahjo Purnomo, Dol LY (Membedah Dunia Pelacuran Surabaya Kasus Kompleks Pelacuran Dolly), Grafiti Pers, Jakarta, 2010

Yopi Gunawan dan Kristian, Perkembangan Konsep Negara Hukum \& Negara Hukum Pancasila, Refika Aditama, Bandung, 2015

\section{B. Peraturan Perundang-Undangan}

Undang-Undang Nomor 1 Tahun 1946 Tentang Aturan Hukum Pidana.

Undang-Undang Nomor 8 Tahun 1981 Tentang Undang-Undang Hukum Acara Pidana.

Undang-Undang Nomor 21 tahun 2007 Tentang Pemberantasan Tindak Pidana Perdagangan Orang.

Undang-Undang Nomor 11 Tahun 2008 Tentang Informasi dan Transaksi Elektronik.

Undang-Undang Nomor 44 Tahun 2008 Tentang Pornografi. 
C. Jurnal, Artikel, Makalah, Majalah,

\section{Koran, Internet, dan Lain-lain}

Amalia, Astry Sandra, "Dampak Lokalisasi Pekerja Seks Komersial (PSK) Terhadap Masyarakat Sekitar (studi Kasus di Jalan Soekarno-Hatta Km. 10 Desa Purwajaya Kabupaten Kutai Kartanegara)", eJournal Administrasi Negara, Volume 1, Nomor 2, 2013.

Anwar Sahid, Polemik Prostitusi di Indonesia, Surat Kabar Harian Media Indonesia, Nomor XIII, 13 Oktober 2016.

Butje Tampi, "Kejahatan Kesusilaan dan Pelecehan Seksual Dalam Hukum Pidana Indonesia”, Karya Ilmiah Universitas Sam Ratulangi Fakultas Hukum Manado, 2010.

Daniel Andreo, "Analisis Juridis Terhadap Pertanggungjawaban Pidana Pelaku Percobaan Tindak Pidana Perdagangan Orang Menurut Undang-Undang Nomor 21 Tahun 2007 (Putusan Pengadilan Negeri Medan Nomor 1.642/Pid.B/2009/PN.Medan)". Jurnal Ilmiah Fakultas Hukum Universitas Sumatera Utara Medan, 2012.

Dian Andriasari, "Studi Komparatif Tentang Zina dalam Hukum Indonesia dan Hukum Turki”, Jurnal Syiar Hukum FH Unisba. Vol. XIII. No. 3 November 2011.

Fahira Idris, di Swedia, "Identitas Pelanggan PSK Dipublikasikan Biar Jera", dalam Selasar.com diakses Jumat, 22 Oktober 2016 06:00 WIB

Helmy Boemiya, "Analisis Yuridis Tindak Pidana Perbuatan Zina (Perzinahan) dalam Perspektif Hukum Islam", T.p.,T.t.

Ishaq, "Kontribusi Konsep Jarimah Zina Dalam Pembaharuan Hukum Pidana Indonesia", Ijtihad, Jurnal Wacana Hukum Islam dan Kemanusiaan Volume 14, No. 1, Juni 2014.

Jimly Asshiddiqie, Cita Negara Hukum Indonesia, Pidato Orasi Ilmiah Pada Wisuda Sarjana Hukum Fakultas Hukum Sriwijaya Palembang Tanggal 23 Maret 2004, dimuat dalam Jurnal Hukum Simbur Cahaya No. 25 Tahun IX Mei 2005.

John Godwin, Pekerjaan Seks dan Hukum di Asia Pasifik: Hukum, HIV, dan Hak Asasi Manusia dalam Konteks Pekerjaan Seks, Oktober, 2012.

Sihombing, G, "Analisis dan Evaluasi Hukum Tentang Penanggulangan Prostitusi dan Pencegahan Penyebaran HIV/AIDS". Badan Pembinaan Hukum Nasional Departemen Kehakiman RI, Jakarta: 1996.

Simangunsong, et.all., "Analisis Yuridis Mengenai Pertanggungjawaban Pidana Pengguna Jasa Prostitusi dalam Perspektif KUHP", T.p., t.t.

Sumiyanto, "Kecenderungan Wanita Menjadi Korban Tindak Pidana terhadap Kesusilaan", T.p., t.t. 